
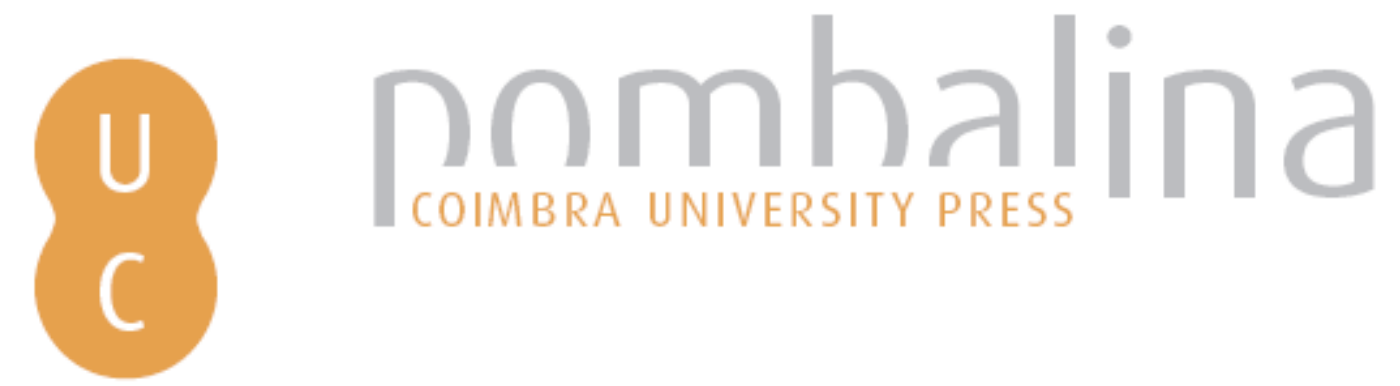

\title{
Pode-se pensar a filosofia aristotélica como modo de vida?: Diógenes Laércio e a sua posteridade na obra de Pierre Hadot
}

Autor(es): $\quad$ Puente, Fernando Rey

Publicado por: Imprensa da Universidade de Coimbra

URL

persistente: URI:http://hdl.handle.net/10316.2/34712

DOI: $\quad$ DOI:http://dx.doi.org/10.14195/978-989-721-042-6_12

Accessed : $\quad$ 26-Apr-2023 12:02:04

A navegação consulta e descarregamento dos títulos inseridos nas Bibliotecas Digitais UC Digitalis, UC Pombalina e UC Impactum, pressupõem a aceitação plena e sem reservas dos Termos e Condições de Uso destas Bibliotecas Digitais, disponíveis em https://digitalis.uc.pt/pt-pt/termos.

Conforme exposto nos referidos Termos e Condições de Uso, o descarregamento de títulos de acesso restrito requer uma licença válida de autorização devendo o utilizador aceder ao(s) documento(s) a partir de um endereço de IP da instituição detentora da supramencionada licença.

Ao utilizador é apenas permitido o descarregamento para uso pessoal, pelo que o emprego do(s) título(s) descarregado(s) para outro fim, designadamente comercial, carece de autorização do respetivo autor ou editor da obra.

Na medida em que todas as obras da UC Digitalis se encontram protegidas pelo Código do Direito de Autor e Direitos Conexos e demais legislação aplicável, toda a cópia, parcial ou total, deste documento, nos casos em que é legalmente admitida, deverá conter ou fazer-se acompanhar por este aviso.

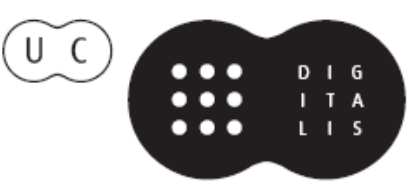




\section{Dos Homens e suas Ideias \\ Estudos sobre as Vidas de Diógenes Laércio}

Delfim Leão, Gabriele Cornelli \& Miriam C. Peixoto (coords.) 


\title{
Pode-SE PENSAR A FILOSOFIA ARISTOTÉLICA COMO MODO DE VIDA? Diógenes Laércio e sua posteridade na obra de Pierre HADOT (Can we think the aristotelian philosophy as a way of life? Diogenes Laertius and his posterity in the work of Pierre Hadot)
}

\author{
Fernando Rey Puente ${ }^{\mathrm{I}}$ \\ Universidade Federal de Minas Gerais
}

\begin{abstract}
Resumo: Nosso objetivo neste texto é o de discutirmos, no âmbito da apresentação da filosofia de Aristóteles exposta por Diógenes Laércio no livro V (parágrafos 28 a 34) de sua célebre obra Vidas e opiniôes dos filósofos ilustres, os parágrafos 30 e 31 dedicados à ética, mais precisamente ainda, é o de analisarmos a noção de bios neles contida a fim de avaliarmos em que medida a apresentação de Diógenes Laércio se distancia da posição de Aristóteles. Por fim, procuraremos mostrar se e, em caso positivo, em que medida a noção da filosofia antiga como modo de vida de Pierre Hadot é, em nossos dias, uma retomada da posição filosófica de Diógenes Laércio.

Palavras-chave: Diógenes Laércio, modo de vida, filosofia, Pierre Hadot
\end{abstract}

Abstract: Our aim in this text is to discuss the paragraphs 30 and 31 about ethics in the presentation of Aristotle's philosophy within the Lifes and Opinions of Eminent Philosophers, more precisely it is to analyze the notion of bios found in this two above mentioned chapters with the purpose to known in which degree the presentation of Diogenes Laertius is distant of the Aristotelian position itself. Last, we try to show if, and, in case of a positive answer, in what measure does Pierre Hadot's notion of ancient philosophy as a way of life is in our days an adaptation of the philosophical position of Diogenes Laertius.

Key-words: Diogenes Laertius, way of life, philosophy, Pierre Hadot

\section{A exposição da filosofia aristotélica por Diógenes Laércio (5.28-34)}

Há três importantes contribuições que nos ajudam a compreender o resumo da filosofia aristotélica tal como apresentado por Diógenes Laércio, a saber, o artigo pioneiro de Paul Moraux, "L'exposé de la philosophie d'Aristote chez Diogène Laërce (V, 28-34)” de 1949², sua reavaliação quase cinquenta anos mais tarde por Moraux em um texto intitulado "Diogène Laërce et le peripatos", publicado em $1986^{3}$, e, por fim, no ano de 1995, o artigo de Richard Bodéüs, "L'aristotélisme stoïcien" ${ }^{4}$ Com base nas exegeses propostas nesses

\footnotetext{
${ }^{1}$ Bolsista do CNPq (Produtividade em pesquisa) e da Fapemig (Pesquisador mineiro).

${ }^{2}$ Cf. Moraux 1949.

${ }^{3}$ Cf. Moraux 1986.

${ }^{4}$ Cf. Bodéüs 1995.
} 
textos, bem como nas notas explicativas a esses parágrafos presentes na tradução francesa de Michel Narcy ${ }^{5}$, Tiziano Dorandi nos propôs recentemente uma nova edição desses parágrafos com algumas notas explicativas em um artigo publicado em 2007 e intitulado "Diogène Laërce 'lecteur' d'Aristote" ${ }^{\text {, edição }}$ esta que evidentemente será igualmente levada em conta em nossa análise dos parágrafos 30 e 31 que correspondem, como se sabe, à exposição da seção sobre a ética aristotélica.

Em seu primeiro artigo, Moraux tem por finalidade investigar todo o resumo da doutrina aristotélica exposta nos parágrafos 28 a 34 e, analisando as seções sobre lógica (28-29), ética (30-31) e física (32-34), ele indica a uma influência estoica que estaria na origem do resumo seguido posteriormente por Diógenes Laércio, um resumo, como bem mostra Moraux, anterior à edição dos livros de Aristóteles feita por Andrônico de Rodes no século I a.C. Logo, este é, muito provavelmente, o mais antigo resumo que nos foi legado da filosofia aristotélica e temos acesso a ele graças ao relato posterior de Diógenes Laércio que analisamos aqui.

$\mathrm{Na}$ divisão da filosofia aristotélica proposta no início do parágrafo 28 , e que constitui uma espécie de introdução ao resumo da doutrina aristotélica, Moraux, apesar de perceber um claro paralelismo com as divisões propostas pelos estoicos, que obedecem à tripartição da filosofia em lógica, ética e física, não julga, contudo, poder comprovar essa influência apenas por causa desse paralelismo, pois, como ele menciona, haveria indícios dessa divisão tripartite em autores anteriores aos estoicos como, por exemplo, Xenócrates, Platão e Aristóteles ${ }^{7}$. O artigo de Bodéüs citado acima, ao contrário, exporá detalhadamente a indubitável influência estoica presente na composição dessa brevíssima introdução ao resumo sobre a filosofia de Aristóteles. Concentremo-nos agora, porém, apenas na análise dos parágrafos 30 e 31 .

Uma mera enumeração dos tópicos tratados resumidamente nesses dois parágrafos, a saber: o fim da vida moral, os diferentes bens e a felicidade, as virtudes e os vícios, o sábio frente às paixões, a amizade, o sábio e o amor, o sábio na vida política e familiar, os diferentes modos de vida e a utilidade das ciências para a aquisição da virtude, nos mostra, como Moraux assinala em seu texto, o quanto esse sumário doutrinal está de acordo com a discussão dessas questões tal como exposta no âmbito do pensamento epicurista e estoico ${ }^{8}$. Moraux passa, a seguir, à exposição de cada um desses tópicos mostrando a clara influência estoica que está por trás de cada um deles. Nosso interesse, entretanto, se resume

\footnotetext{
${ }^{5}$ Cf. Goulet-Cazé 1999 541-593.

${ }^{6}$ Cf. Dorandi 2007.

${ }^{7}$ Cf. Moraux 1949 9. Cf. Bodéüs 1995.

${ }^{8}$ Cf. Moraux 194918.
} 
a analisar apenas dois desses tópicos, pois neles estão contidas as duas únicas ocorrências do termo bios. Os dois tópicos que discutiremos são: o que aborda a finalidade da vida moral e o que menciona os diferentes modos de vida.

Com relação ao primeiro, lapidarmente formulado na sentença: "Propôs

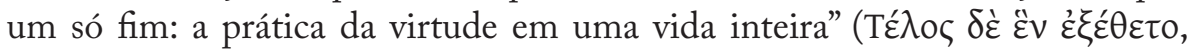

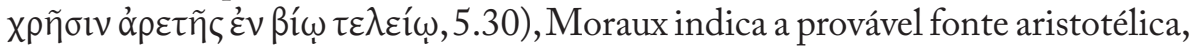
a saber, o passo 1098a16-20 do livro I da Ética a Nicômaco9. Mais tarde, analisaremos o passo em questão, por ora, mencionemos apenas a indubitável influência estoica atestada por Moraux ao constatar o uso frequente de sentenças provenientes de filósofos estoicos relativas à finalidade da vida e exemplificadas pelo próprio Diógenes Laércio nos parágrafos 87 e 88 do livro VII de sua obra onde, inclusive, faz alusão a livros intitulados Sobre os fins escritos por alguns desses filósofos estoicos ${ }^{10}$.

Com relação ao segundo, Diógenes Laércio afirma sumariamente: "Há três modos de vida: teorética, prática e hedonista, destas < Aristóteles> escolhe

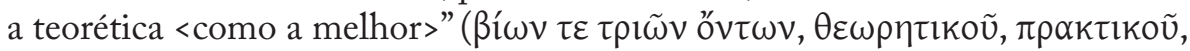

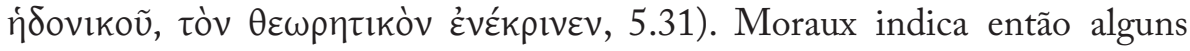
passos da obra de Aristóteles onde tal divisão é encontrada (EN 1.1095b19, Pol. 7.1324a28 e EE 1.1215a30), bem como assinala o fato que Diógenes Laércio resume, quase nos mesmos termos que usa para falar de Aristóteles, a posição dos estoicos relativa aos três modos de vida (cf. 7.130: Bíwv $\delta \dot{\varepsilon} \tau \rho i \tilde{\omega} v$

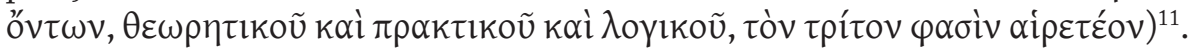
Notemos apenas que, no caso dos estoicos, o modo de vida que, segundo eles, deve ser escolhido é o racional ou lógico e não o teorético, o que deixa subentender uma distinção entre esses termos, mas deixemos a análise desse passo igualmente para uma seção ulterior de nosso texto.

Em seu artigo de 1986, Moraux repensa alguns pontos expostos em seu texto seminal de 1949. Ele enfatiza o quanto o resumo doutrinal só aparece em Diógenes Laércio ao falar do criador de uma escola. Assim, no caso do livro $\mathrm{V}$, apenas da filosofia de Aristóteles é oferecido um brevíssimo resumo, isto porque o que interessava a Diógenes era a diferença entre as escolas, não entre os membros dessas escolas, de modo que na sua perspectiva não haveria nenhuma diferença doutrinal entre Aristóteles, Teofrasto, Estratão ou qualquer outro filósofo mencionado no livro $\mathrm{V}^{12}$.

No que diz respeito aos parágrafos consagrados à discussão da parte ética da filosofia de Aristóteles, objeto de nosso texto, Moraux nos faz ver ademais

\footnotetext{
${ }^{9}$ Cf. Moraux 194918.

${ }^{10}$ Cf. Moraux 194919.

${ }^{11}$ Cf. Moraux 194929.

${ }^{12}$ Cf. Moraux 1986 266-267.
} 
o quanto os tópicos neles abordados e que enumeramos acima nada mais seriam do que respostas a questões que Diógenes Laércio, como os demais doxógrafos formulariam para entender cada autor estudado, a fim de que seu relato contivesse uma unidade temática de exposição. Assim, as questões que presidem ao resumo ético do pensamento de Aristóteles não são diferentes daquelas que estruturaram a exposição da Ética de Platão (cf. 3.78-79). Mas, mais importante, o plano que perpassa essas questões só se apresenta em toda a sua extensão na importante exposição que Diógenes Laércio dedica aos estoicos (cf. 7.84-131). Em suma, Moraux, apoiando-se na preciosa obra de M. Giusta ${ }^{13}$ sobre os doxógrafos de ética, mostra que havia um modo tradicional de expor as posições teóricas de um autor confrontando-o com um conjunto de questões relativas a certos temas de ética ${ }^{14}$. O que nos interessa destacar aqui, mais uma vez, é a influência do estoicismo na elaboração dessas questões, pois, como se sabe, muitas delas não tinham interesse algum para Aristóteles, como é o caso da relação do sábio com a família e a política ou com a noção de providência, tema estranho ao pensamento do Estagirita. Com isso, evidentemente nos aproximamos mais da interpretação proposta por R. Bodéüs do que da proposta por P. Moraux que prefere concluir seu artigo afirmando apenas que os parágrafos consagrados à exposição da ética de Aristóteles não correspondem às posições do próprio Aristóteles, mas seriam apenas as respostas às questões que os doxógrafos colocariam para cada fundador de uma seita filosófica em sua exposição comparativa das distintas escolas $^{15}$.

$\mathrm{O}$ artigo de $\mathrm{R}$. Bodéüs é-nos particularmente importante não porque analise detalhadamente os parágrafos que nos interessam estudar neste texto, o que na verdade não faz, mas sim porque ele assinala muito bem, em contraposição a P. Moraux, que o relato de Diógenes Láercio sobre a doutrina de Aristóteles não é incoerente, antes profundamente coerente, afirmando, além disso, que a razão dessa coerência e unidade é precisamente a inspiração estoica do mesmo ${ }^{16}$. Todo o artigo de R. Bodéüs visa mostrar, por conseguinte, que a introdução aos placita, ou seja, o brevíssimo início do parágrafo 28, foi redigido sob profunda inspiração estoica, isto é, não apenas nos demais parágrafos da exposição da doutrina de Aristóteles haveria a influência estoica, algo que já havia sido apresentado por P. Moraux desde seu artigo seminal de 1949, mas até mesmo nessa breve introdução a eles pode-se claramente evidenciar o estoicismo que lhe é subjacente.

\footnotetext{
${ }^{13}$ Cf. Giusta 1964 e 1967.

${ }^{14}$ Cf. Moraux 1986 273-274.

${ }^{15}$ Cf. Moraux 1986280.

${ }^{16}$ Cf. Bodéüs 19959.
} 
Por fim, cabe dizer que o breve artigo de T. Dorandi não nos aporta nenhuma nova consideração relevante sobre os parágrafos 30 e 31, seja do ponto de vista da edição do texto grego, seja por seus comentários a esses dois parágrafos.

\section{Algumas particularidades da exposição 'doxográfica' de Diógenes Laércio}

Gostaríamos de expor brevemente alguns aspectos metodológicos do relato de Diógenes Laércio que devemos levar em conta em nossa posterior consideração sobre a noção de bios em seus dois breves parágrafos sobre a ética de Aristóteles.

Para essas reflexões metodológicas nos apoiaremos sobretudo nos trabalhos de $\mathrm{M}$. Frede ${ }^{17}$ e de A. Laks ${ }^{18}$, no que diz respeito à discussão sobre o gênero doxográfico na Antiguidade, bem como nas pesquisas de M. Gigante ${ }^{19}$ e M. Sollenberger ${ }^{20}$, no que se refere ao entendimento da metodologia subjacente ao texto de Diógenes Laércio.

Constatamos que o texto de Diógenes Laércio se baseia em um relato pré-andrônico da filosofia de Aristóteles, relato este redigido sob forte influência estoica por volta do século II a.C.. Ademais, vimos também que o texto de Diógenes Laércio parece obedecer a um protocolo de questões que os doxógrafos faziam aos fundadores das escolas que queriam expor a fim de extrair desses pensadores informações paralelas mais facilmente postas em confronto que permitiriam, assim, melhor elucidar a posição característica de cada escola. Como pudemos observar, a finalidade dos doxógrafos não era de modo algum a de distinguir diferentes filosofias individuais no interior de cada escola, mas apenas a de evidenciar as diferenças das posições filosóficas entre as escolas.

$\mathrm{Na}$ análise de M. Sollenberger, as linhagens iônica e itálica, descritas por Diógenes Laércio no prólogo da sua obra, culminam nas quatro maiores escolas éticas presentes na era helenística, a saber, a dos estoicos, a dos acadêmicos, a dos peripatéticos e, por fim, a dos epicuristas ${ }^{21}$. Isto quer dizer que no prólogo às Vidas e opinióes Diógenes terminava a sucessão dos peripatéticos com Teofrasto, excluindo assim Estratão da mesma, pois este se destacava por seus estudos físicos, como se pode ler no livro V. Há, portanto, uma evidente incompatibilidade entre a sucessão dos peripatéticos tal como exposta no

\footnotetext{
${ }^{17}$ Cf. Frede 1992.

${ }^{18}$ Cf. Laks 2007.

${ }^{19}$ Cf. Gigante 1986.

${ }^{20}$ Cf. Sollenberger 1992.

${ }^{21}$ Cf. Sollenberger 19923798.
} 
prólogo e tal como ela é apresentada no livro V. Nosso interesse aqui é apenas o de chamar a atenção para a importância da ética nesse primeiro esboço de sucessão escolar, contido no prólogo, pois é no interior desse domínio que nos propomos investigar a noção de bios.

M. Sollenberger caracteriza em seu artigo quinze tópicos que estão presentes nas diversas biografias apresentadas por Diógenes Laércio, ao menos nas biografias dos fundadores de uma escola (este é o caso, por exemplo, dos peripatéticos, pois apenas a biografia sobre Aristóteles contém todos os quinze itens). Em outras palavras: o relato de Diógenes Laércio obedece claramente a um modelo de escrita que reaparece a cada nova exposição de uma escola. Isto significa, como já vimos, que as diferenças entre os sucessores no interior de uma dada escola ficam obliteradas, pois não interessa a ele diferenças doutrinais individuais, mas apenas diferenças doutrinais entre as escolas. Com isso, ele assume implicitamente a tese que os seguidores de um dado fundador de uma escola filosófica professariam a mesma doutrina que a de seu fundador ${ }^{22}$.

M. Gigante nos esclarece, na mesma direção, a importância fundamental para a elaboração do texto de Diógenes Laércio das noções de hairesis (escola) e de diadoche (sucessão) ${ }^{23}$. Enfatiza, além disso, o que nos interessa particularmente devido a escolha de nosso objeto de estudo neste texto, a importância da noção de ethos na composição dos livros IV e $\mathrm{V}^{24}$.

Vê-se, portanto, que a composição das Vidas de Diógenes Laércio é bastante elaborada, nada tendo de ingênua ou fortuita, mas, representaria ela, de fato, uma posição filosófica? Para responder a essa questão será preciso indagar como devemos pensar a doxografia em nossos dias. Levando em conta que a criação dos termos 'doxógrafo' e 'doxografia' é bastante recente, pois ambos os termos foram inventados por H. Diels, como bem nos lembra A. Laks, e datam apenas do final do século XIX (1879 e 1893 respectivamente) $)^{25}$, é evidente que devemos analisar com desconfiança o uso ingênuo que deles ainda se faz. $\mathrm{O}$ que queremos dizer por uso ingênuo nada mais é do que a crença que o relato de Diógenes Laércio representaria somente um apanhado de opiniões e anedotas sobre filósofos ilustres colhidas ao acaso e sem nenhuma intenção ou mesmo sem nenhum pressuposto filosófico. Hoje em dia, ao contrário, é preciso afirmar com A. Laks que "a doxografia é uma atividade essencial à atividade filosófica” e que tem por finalidade, ainda nos termos de A. Laks, buscar na obra dos predecessores sobre os quais escreve posições filosóficas defensáveis ${ }^{26}$. Seguindo as argutas considerações expostas por M. Frede em

\footnotetext{
${ }^{22}$ Cf. Sollenberger 1992 3855-3856.

${ }^{23}$ Cf. Gigante 198645.

${ }^{24}$ Cf. Gigante 1986 72-74.

${ }^{25}$ Cf. Laks 200714 n. 7.

${ }^{26}$ Cf. Laks 200715.
} 
seu artigo de 1992 sobre a noção de doxografia, A. Laks aponta para o aspecto filosófico dessa reconstrução racional das posições filosóficas dos predecessores, aspecto este que estaria presente no relato dos chamados doxógrafos antigos. Assim, sempre na esteira de M. Frede, A. Laks afirma que a única distinção entre a reconstrução racional que encontramos hoje em dia num trabalho historiográfico e a reconstrução doxográfica de um Diógenes Laércio, por exemplo, é que em nossos dias esse tipo de reconstrução é feito com base nos argumentos presentes nas obras dos diferentes autores ${ }^{27}$ enquanto em Diógenes Laércio ela é alicerçada na noção de escolha de um determinado modo de vida feita a partir da caracterização de diferentes escolas filosóficas. Infelizmente, precisamente essa noção de escolha de uma doutrina, que parece ser um aspecto essencial da doxografia tal qual a concebe Diógenes Laércio, não é tratada em detalhes por M. Frede em seu excelente artigo. Essa ideia, contudo, nos é particularmente cara, visto que nos propomos analisar neste texto é justamente a noção de modo de vida.

Como M. Frede afirma com clareza em seu texto, duas são as premissas que parecem guiar os doxógrafos da Antiguidade, a saber: a) a de que todas as posições filosóficas do passado continuam a ter um interesse filosófico atual e b) a de que as opiniões ou posições assumidas pelos filósofos não são o resultado de uma sequência de argumentos e de demonstrações racionais, mas sim de um caminho e de uma escolha individual ${ }^{28}$. Essa escolha, porém, não deve ser entendida, como talvez fossemos levados a pensar hoje em dia, como uma escolha inconsciente e irracional, mas sim como uma escolha racional alicerçada em uma reflexão atenta sobre as distintas posições das diversas escolas de filosofia disponíveis na época ${ }^{29}$. Como M. Frede nos diz:

o pressuposto segundo o qual uma opinião filosófica não resulta absolutamente de uma demonstração irrefutável, mas de um processo muito mais complexo, nos ajuda a explicar porque, geralmente, os doxógrafos não reproduzem os argumentos sobre os quais os filósofos se apoiavam para propor a opinião deles ${ }^{30}$.

Esse aspecto do que os doxógrafos julgam ser razoável, plausível e agradável e para o qual usam frequentemente o termo areskonta (placita) é o princípio estruturador de seus relatos, mas infelizmente o artigo de M. Frede, como dissemos, não se detém nesse ponto (o item b) acima aludido, mas prefere se concentrar no aspecto atual das posições filosóficas pretéritas. Dizemos

\footnotetext{
${ }^{27}$ Cf. Laks 200723.

${ }^{28}$ Cf. Frede 1992314.

${ }^{29}$ Cf. Frede 1992315.

${ }^{30}$ Frede 1992315.
} 
infelizmente, pois é justamente esse ponto que guarda um estreito paralelismo com a noção que investigaremos na última seção de nosso texto, qual seja a noção de modo de vida, pois esta necessariamente pressupõe a ideia de uma escolha que deve ser feita entre os diferentes modelos apresentados.

Duas reflexões de M. Frede são ainda dignas de menção. Primeiramente, a sua clara percepção de que a discrepância entre a exposição contida no prólogo de Diógenes Laércio e nos livros posteriores nada mais indica do que a diferença entre uma perspectiva de historiador da filosofia, exposta no prólogo à sua obra, e a de um doxógrafo, apresentada nos demais livros. $\mathrm{Ou}$ seja: Diógenes Laércio possuía uma noção "muito elaborada", nas palavras do próprio M. Frede, sobre a história da filosofia e que ele apresenta no prólogo de sua célebre obra, mas, mesmo de posse dessa noção, ele prefere apresentar nos livros posteriores as diferentes escolas e suas sucessões como posições filosóficas atualmente passíveis de serem escolhidas, ou seja, faz obra de doxógrafo ${ }^{31}$. Segundo M. Frede, a principal escola responsável por essa concepção historiográfica teria sido a dos céticos, dado que eles tratavam as opiniões pregressas como se fossem posições contemporâneas dispostas no mesmo espaço lógico. Para eles, portanto, não haveria uma evolução ou um progresso da filosofia, mas, nas palavras de M. Frede, "a acumulação em um plano horizontal de possibilidades que viriam a se neutralizar reciprocamente" 32 . Ora, levando isso em conta, percebe-se que se em seu prólogo Diógenes Laércio afirmava o nascimento da filosofia a partir de uma sabedoria pré-filosófica, em uma clara perspectiva progressista, na apresentação das diversas escolas e de suas sucessões internas nos livros posteriores, ele não parece preocupado em apresentá-las sucessiva ou progressivamente, mas sim em fazê-las culminar nas quatro grandes escolas éticas presentes na sua época que estariam sendo apresentadas aos seus leitores, portanto, como posições filosóficas passíveis de serem por eles escolhidas mediante uma decisão racional; esta então, parece ter sido a finalidade última do modo de exposição doxográfico de Diógenes Laércio.

\section{A noção de bios theoretikos em Aristóteles segundo as interpretações de P. Hadot, C. Natali e E. Berti}

No século XX graças ao trabalho de P. Hadot sobre filosofia antiga, intérprete que teve uma ampla e profunda repercussão internacional, popularizou-se a noção de que a filosofia antiga deve ser entendida como uma maneira de viver. Antes mesmo de sua difusão por P. Hadot, essa ideia, como

\footnotetext{
${ }^{31}$ Cf. Frede 1992 318-319.

${ }^{32}$ Frede 1992320.
} 
se sabe, já havia sido explorada mais circunscritamente por P. Rabbow ${ }^{33}$ e por I. $\mathrm{Hadot}^{34}$ em obras que, como se sabe, influenciaram profundamente P. Hadot ${ }^{35}$.

Em seu artigo "La philosophie comme manière de vivre" ${ }^{36} \mathrm{P}$. Hadot expõe com bastante clareza sua tese. Citando uma passagem de Filo de Alexandria, inspirada pelo estoicismo, ele afirma que a filosofia na época helenística e romana era uma maneira de viver, o que não deveria ser entendido simplesmente, a seu ver, como a mera adoção de certa conduta moral por parte dos filósofos, mas sim como a adoção de um modo de existir no mundo que deve ser praticado a cada instante e que deve transformar toda a vida. No mesmo tom, de clara inspiração existencialista, ele reitera poucas linhas depois que "a filosofia era um método de progresso espiritual que exigia uma conversão radical, uma transformação radical da maneira de ser" ${ }^{37}$. A fim de melhor explicitar nesse artigo em que sentido a filosofia antiga deveria ser compreendida como um modo de vida P. Hadot se baseia em uma passagem de Diógenes Láercio (cf. 7.39) na qual o célebre doxógrafo da Antiguidade distingue entre o discurso sobre a filosofia e a própria filosofia. Segundo P. Hadot, nessa passagem que fala da tripartição da filosofia em física, ética e lógica, o que os estoicos queriam de fato defender não era que a filosofia fosse em si mesma tripartite, mas sim que o discurso sobre a filosofia era tríplice, de modo que para ensinarmos a filosofia deveríamos ensinar uma teoria física, uma teoria ética e uma teoria lógica, mas, nas palavras de P. Hadot:

A filosofia ela mesma, isto é, o modo de vida filosófico não é uma teoria dividida em partes, mas um ato único que consiste em viver a lógica, a física e a ética. Não se faz mais então a teoria da lógica, isto é, o bem falar e o bem pensar, mas se pensa e se fala bem, não se faz mais a teoria do mundo físico, mas se contempla o cosmo, não se faz mais a teoria da ação moral, mas se age de uma maneira reta e justa ${ }^{38}$.

A favor de sua interpretação sobre o significado da filosofia na Antiguidade P. Hadot recorre mais uma vez a Diógenes Laércio citando um passo do livro IV (4.18) no qual este se refere a Pólemon, um dos chefes da antiga Academia, que dizia:

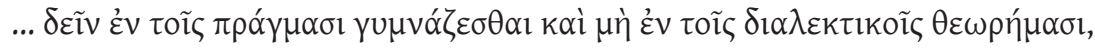

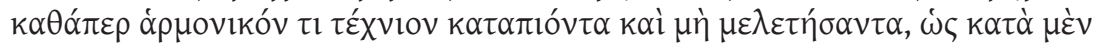

\footnotetext{
${ }^{33}$ Cf. Rabbow 1954.

${ }^{34}$ Cf. I. Hadot 1969.

${ }^{35}$ Cf. Desroches 20112.

${ }^{36} \mathrm{Cf}$. P. Hadot 1987 . Este artigo foi redigido pela primeira vez nos anos de 1975-76.

${ }^{37}$ P. Hadot 1987218.

${ }^{38}$ P. Hadot 1987220.
} 


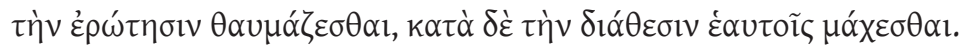

É preciso exercitar-se nos afazeres [da vida] e não em especulações dialéticas, assim como alguém que se embriagou com um manualzinho de harmonia, mas não $<0>$ praticou, de modo que tais homens causariam admiração pelo questionamento, mas estariam em conflito consigo mesmos quanto ao seu comportamento.

$\mathrm{Na}$ visão de P. Hadot, essa distinção, embora formulada apenas pelos estoicos, era "admitida implicitamente pela maior parte dos filósofos" ${ }^{39}$. Sua ideia, portanto, é a de que a filosofia como ação viva distanciava-se muito da teoria filosófica e que o objetivo da filosofia na Antiguidade era o de buscar uma transformação de si mesmo. Epicuristas e estoicos, por conseguinte, entendiam a filosofia como um ato permanente identificado à própria vida e este ato P. Hadot julga adequado definir com "uma orientação da atenção" ${ }^{40}$. Ele conclui suas observações sobre a filosofia antiga com uma referência explícita a Aristóteles que nos interessa em especial e por isso a citaremos na íntegra:

Pensa-se às vezes que Aristóteles é um teórico puro, mas para ele também a filosofia não se reduz ao discurso filosófico ou a um corpus de conhecimentos, mas é uma qualidade do espírito, o resultado de uma transformação interior: a forma de vida que ele preconiza é a de viver consoante o espírito (EN1178ass).

Em sua obra posterior, Qu'est-ce que la philosophie antique?41, P. Hadot se aprofunda ainda mais na sua interpretação da filosofia de Aristóteles como sendo um modo de vida. Reconhecendo inicialmente que a interpretação habitual que se faz da filosofia de Aristóteles estaria em oposição frontal à interpretação da filosofia antiga como modo de vida, P. Hadot se esforça então por inserir o Estagirita nessa concepção, que ele acredita ser a da filosofia antiga em geral.É importante notar que nesse ponto a posição de M. Foucault diverge radicalmente da de P. Hadot, como uma nota de seu curso dos anos 1981-2 no Collège de France testemunha, nota onde M. Foucault afirma enfaticamente a singularidade de Aristóteles em relação à tradição grega anterior a ele, bem como a influência que essa posição singular de Aristóteles teve na formação da filosofia moderna ${ }^{42}$.

${ }^{39}$ P. Hadot 1987220.

${ }^{40}$ P. Hadot 1987221.

${ }^{41}$ Cf. P. Hadot 1995.

${ }^{42}$ Cf. Foucault 2001 18-19 : "Digamos esquematicamente isto: durante todo esse período que denominamos Antiguidade e, segundo modalidades que foram bem diferentes, a questão filosófica de 'como ter acesso à verdade?' e a prática da espiritualidade (as transformações necessárias no ser mesmo do sujeito que vão permitir o acesso à verdade), bem, essas duas 
P. Hadot se apóia sobretudo na sua interpretação que a filosofia aristotélica, apesar de conceder uma importância indubitável à observação, análise e pesquisa especialmente dos seres vivos, tinha na vida do espírito o seu objetivo final. P. Hadot ademais chama a atenção do leitor para o fato de ser preciso diferenciar entre os termos "teorético" e "teórico" no pensamento do Estagirita. Segundo ele, Aristóteles usa o termo "teórico" poucas vezes e sempre em um registro não filosófico relacionado às procissões. Para nós, entretanto, teórico se opõe a prático e nós projetamos essa nossa dicotomia no pensamento de Aristóteles, mas fazemos isso erroneamente como nos adverte o intérprete francês. O vocábulo "teorético", por outro lado, é usado frequentemente pelo Estagirita para indicar o modo de conhecimento que tem o próprio saber como finalidade, um conhecimento privado, portanto, de qualquer tipo de aplicação, mas também para indicar, nas palavras do próprio P. Hadot, "o modo de vida que consiste em consagrar a sua vida a esse modo de conhecimento". Mais importante ainda, como ele destaca: "Nesse último sentido, 'teorético' não se opõe a 'prático', dito de outro modo, 'teorético' pode se aplicar a uma filosofia praticada, vivida, ativa, que traz a felicidade" ${ }^{43}$. Essa leitura de P. Hadot se alicerça sobretudo em um passo da Política de Aristóteles que ele traduz e comenta e que citamos segundo a sua tradução:

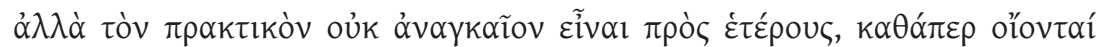

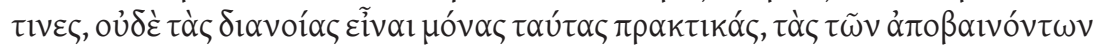

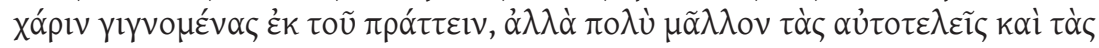

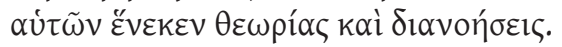

A vida prática não é necessariamente dirigida a outrem, como pensam alguns, e não são apenas os pensamentos que visam resultados que serão produzidos pelo agir que serão 'práticos', pois são 'práticos', muito mais ainda, as atividades

questões, esses dois temas jamais foram separados. Eles não foram separados para os pitagóricos, e isso é evidente. Tampouco eles foram separados para Sócrates e Platão: a epimeleia heautou (cuidado de si) designa precisamente o conjunto de condições necessárias para que possamos ter acesso à verdade. Logo, durante toda a Antiguidade (nos pitagóricos, em Platão, nos estoicos, nos cínicos, nos epicuristas, nos neoplatônicos, etc.), jamais o tema da filosofia (como ter acesso à verdade?) e a questão da espiritualidade (quais são as transformações no próprio ser do sujeito necessárias para ele ter acesso à verdade?), jamais essas duas questões foram separadas. A maior e mais importante exceção: a que é constituída por aquele que nós denominamos 'o' filósofo, dado que ele foi na Antiguidade, sem dúvida, o único filósofo, dentre todos os demais, para o qual a questão da espiritualidade foi a menos importante. Aquele no qual nós reconhecemos o próprio fundador da filosofia no sentido moderno do termo, Aristóteles. Mas, como todos sabem, Aristóteles não representa o ápice da Antiguidade, mas a exceção". Na mesma direção dessa interpretação podemos citar também o testemunho de Simone Weil, uma pensadora diametralmente oposta a M. Foucault: "Aristóteles é talvez na Grécia o único filósofo no sentido moderno e, de fato, totalmente alheio à tradição grega" (cf. Weil 1953 77, ênfase de SW).

${ }^{43}$ Cf. P. Hadot 1995129. 
do espírito (theoriai) e as reflexões que possuem seu fim nelas mesmas e são desenvolvidas em vista de si mesmas... (Pol. 7.1325b16-21) ${ }^{44}$

Ora, como nos esclarece P. Hadot, se Aristóteles associa a ação perfeita à vida teorética, então a filosofia teorética já seria, na verdade, uma ética, uma ética do desinteresse e da objetividade nas palavras do intérprete francês ${ }^{45}$.

Em suma, P. Hadot termina sua exposição sobre Aristóteles inserindo-o na escola platônica a qual pertence e condividindo, portanto, com os demais membros dessa escola a distinção por eles aceita, de acordo com o intérprete francês, entre o discurso filosófico e a vida filosófica.

Evidentemente, a noção de bios, ou seja, de um "modo de vida" está presente em Aristóteles, mas seria legítimo afirmar que o sentido que Aristóteles atribui ao termo é idêntico àquele conferido a ele por P. Hadot?

Carlos Natali que dedicou todo um livro para analisar o significado do tipo de vida que Aristóteles defendeu, afirma, a partir de outra perspectiva exegética, que "com Aristóteles aperfeiçoa-se um novo tipo de intelectual, diverso daqueles da idade precedente e particularmente importante, como modelo, para muitos séculos por vir" ${ }^{\$ 6}$. $\mathrm{Na}$ sua interpretação, para Aristóteles, contrariamente a Sócrates, "faltou qualquer tendência ao proselitismo missionário, isto é, a conceber a própria escolha de vida como um 'testemunho' que englobasse não apenas o trabalho propriamente intelectual, mas toda a personalidade do sujeito" ${ }^{47}$. $\mathrm{Na}$ exegese de C. Natali, portanto, Platão e Aristóteles assinalariam um distanciamento progressivo do modelo socrático, uma institucionalização do diálogo socrático na dialética, presente em ambos. Um forte indício nessa direção é atestado por C. Natali através de um passo da Ética a Nicômaco no qual Aristóteles critica Eudoxo por este "convencer mais por meio de seu caráter excelente do que por seus próprios argumentos" (cf.

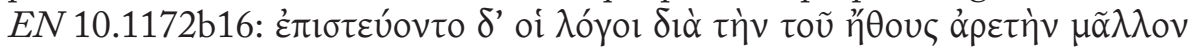

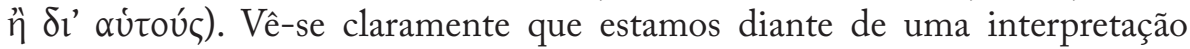
completamente divergente daquela proposta por P. Hadot, pois nesse passo da Ética a Nicômaco fica muito evidente a importância que Aristóteles concede à argumentação. Sem dúvida, para Aristóteles, assim como para Platão, sempre na visão de C. Natali, "a filosofia foi a escolha de um bios, de um modo de passar a vida e de atualizar da melhor maneira a capacidade própria do homem, foi, em uma palavra, a escolha de um modo de ser feliz" ${ }^{48}$, mas isso não quer dizer que essa escolha signifique um exercício de atenção no sentido que P. Hadot

\footnotetext{
${ }^{44}$ Cf. P. Hadot 1995129.

${ }^{45}$ Cf. P. Hadot 1995 129-130.

${ }^{46}$ Natali 199167.

${ }^{47}$ Natali 199169.

${ }^{48}$ Natali 199170 .
} 
atribui ao termo. A passagem que P. Hadot cita da Ética a Nicômaco parece antes corroborar uma tese oposta à por ele mesmo defendida, pois no passo 10.1178b20-21 Aristóteles se pergunta: "no caso dos seres vivos, afastada a

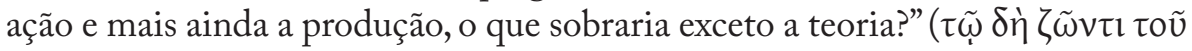

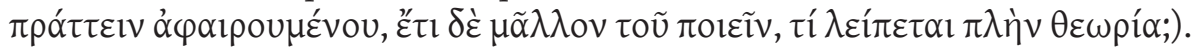
Ora, a ideia expressa nesse passo não parece ser a de que "viver consoante o espírito”, segundo a tradução de P. Hadot, seria atualizar na própria vida, por meio de um exercício de atenção, o discurso filosófico, mas sim a de que colocando de lado a ação e a produção restaria apenas a teoria, ou seja, a atividade intelectual. $\mathrm{O}$ discurso filosófico, portanto, não parece ser atualizado na vida, como pensa P. Hadot (a partir de uma concepção filosófica oriunda da filosofia helenística), mas antes parece indicar apenas que, excluindo a ação e a produção, resta a atividade teórica ou teorética que é evidentemente valorizada, pois é semelhante à atividade do próprio Deus. Isto não quer dizer, contudo, que essa atividade teorética acarrete uma transformação de toda a pessoa, antes ela parece indicar apenas a realização máxima a que o homem pode chegar, ainda que somente por algum tempo, da atividade auto-contemplativa eterna do próprio Deus.

A grande dificuldade na interpretação dessa e de outras passagens de Aristóteles, como o próprio C. Natali reconhece, é a de saber o que significaria exatamente o termo theoria para o Estagirita. As opções tradicionais vão desde interpretá-lo como sendo a contemplação da divindade (sugestão de Gauthier) até considerá-lo como sendo a vida de pesquisa científica (tese de Düring) passando pela tentativa de juntar as duas interpretações aparentemente discrepantes (tese de Erikson) ${ }^{49}$.

Uma proposta muito interessante de pensar a relação entre práxis e teoria em Aristóteles foi apresentada por E. Berti em um artigo publicado originalmente em 1977 e reeditado mais recentemente nas suas obras reunidas ${ }^{50}$ O intérprete italiano começa mostrando como a noção de poiein (fazer) em Aristóteles pode ter um significado genérico que englobaria tanto a teoria quanto a práxis como um significado específico no interior do qual o produzir (poiein) se oporia ao agir (prattein). No interior da praxis Aristóteles distingue com clareza entre uma ação perfeita (teleia), que possui o fim em si mesma (por exemplo: ver, conhecer e pensar) e uma ação imperfeita (ateles), que possui o fim em outra coisa (por exemplo: emagrecer, aprender e caminhar). Logo, a praxis tem por finalidade a própria ação diferentemente da poiesis que visa o artefato a ser produzido.

\footnotetext{
${ }^{49}$ Cf. Natali 199193 n. 1.

${ }^{50}$ Cf. Berti 2008 9-23.
} 
Mas, sempre seguindo a exegese de E. Berti ${ }^{51}$, é preciso não confundir entre ação imanente e a teoria em Aristóteles. $\mathrm{O}$ fim da ação não é outro do que a boa conduta (eupraxia) do homem enquanto o fim da teoria é ela mesma. No primeiro caso, o fim é imanente ao próprio homem, no segundo, a teoria não possui fim em sentido próprio. Em suma, e isso é o mais importante para o nosso confronto dessa interpretação com a de P. Hadot: no caso da ação, ocorre uma transformação no próprio homem que realiza essas ações virtuosas com o intuito de buscar a vida feliz, no caso da teoria ocorre uma transformação em algo diverso do homem sem, contudo, transformar nem o próprio homem nem esse algo diverso que nele habita (o nous) e, por fim, no caso da produção, ela ocorre fora do homem e com a finalidade de transformar isso no qual ela ocorre.

A chave para entender a relação entre práxis e teoria em Aristóteles para E. Berti é constituída pela relação de meio e fim, como ele nos esclarece em um passo desse artigo e que citamos na íntegra:

Entre teoria e práxis, de fato, Aristóteles não estabelece uma relação de oposição ou de alternativa, antes uma relação de sucessão ou de continuidade. Eis a razão pela qual primeiro a teoria (aplicada) é meio em vista da práxis (correta) e depois a práxis (correta) é meio em vista da teoria (pura). A chave para entender a doutrina completa é a relação de meio e fim, indicada desde o princípio na distinção entre ação perfeita e ação imperfeita ${ }^{52}$.

Assim, se a phronesis é um meio para agir corretamente, esta ação correta, por sua vez, nos conduz à atividade teorética. Cabe dizer, entretanto, a favor de P. Hadot, que E. Berti ignora neste artigo a importante passagem da Política à qual o intérprete francês faz referência. Mais ainda, quando P. Hadot a traduz, ele deixa de traduzir umas linhas posteriores ao passo em questão que dão indícios ainda mais fortes na direção de sua interpretação, pois Aristóteles tentando explicar sua concepção afirma que "dizemos que agem em sentido pleno também aqueles que comandam ações exteriores pelos seus pensamentos"

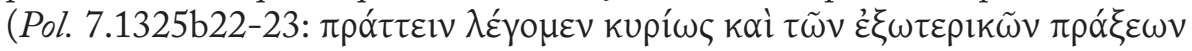

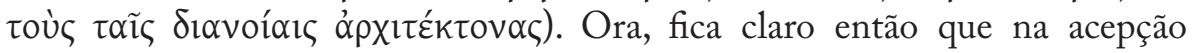
principal (kyrios) de prattein (agir) o pensamento (dianoia) para Aristóteles já parece ser uma ação.

Dessas interpretações discordantes, resta-nos aqui apenas constatar a complexidade e a irresolução exegética em como compreender o sentido último de bios theoretikos no pensamento de Aristóteles. Sem dúvida, isso exigiria refletir sobre um dos pontos mais obscuros, mas mais essencias da doutrina

\footnotetext{
${ }^{51}$ Cf. Berti 2008 9-11.

52 Berti 200814.
} 
aristotélica, a saber, a concepção de nous, algo impossível de ser realizado no âmbito deste texto.

\section{Diógenes Laércio e sua interpretação da noção de bios no resumo doutrinal sobre Aristóteles contido nos parágrafos 30 e 31 do livro V das Vidas}

Finalmente, após esse longo, mas necessário percurso pelas características da doxografia de Diógenes Laércio e pelas interpretações de P. Hadot sobre a filosofia antiga como modo de vida, retornemos ao nosso objetivo central, qual seja, o de analisar as duas passagens contidas no resumo doutrinal proposto por Diógenes Laércio da doutrina de Aristóteles.

Já vimos (graças aos trabalhos de P. Moraux e R. Bodéüs) que o relato de Diógenes Laércio sobre a doutrina de Aristóteles está fortemente inspirado no estoicismo. Relembremos os dois passos que estarão aqui sob nosso escrutínio na medida em que neles o célebre 'doxógrafo' da Antiguidade ao tratar das concepções éticas de Aristóteles explicitamente menciona o termo bios:

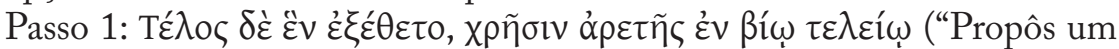
só fim: a prática da virtude em uma vida inteira") e

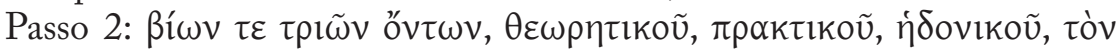

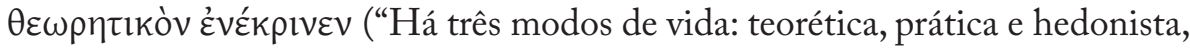
destas [Aristóteles] escolhe a teorética [como a melhor]").

Com relação à primeira passagem, Moraux já tinha constatado a influência estoica, apesar de esse trecho remeter claramente a um passo (1.1098a16-20) da Ética a Nicômaco de Aristóteles. Traduzamo-lo, a seguir. Aristóteles no livro I da $E N$ diz o seguinte: "o bem humano é uma atividade da alma conforme a virtude e, se as virtudes são várias, segundo a melhor e a mais completa; além

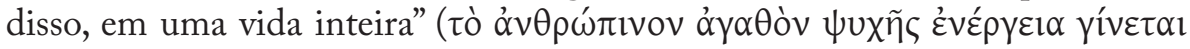

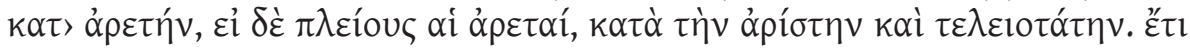

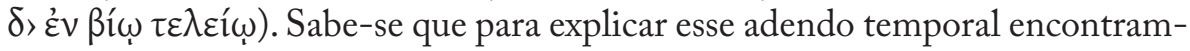
se as referências ao ditado popular que uma andorinha sozinha não faz verão nem tampouco este pode ser constituído por um só dia de sol. Analogamente, afirma Aristóteles: "um só dia ou um breve tempo não faz ninguém feliz e

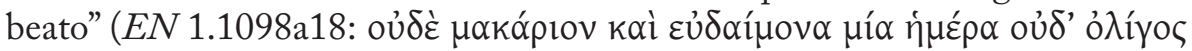
хро́vo५).

No primeiro passo de Diógenes Laércio o termo bios significa então claramente a vida virtuosa. Nesse domínio da ética, percebe-se a distância que há entre a ética aristotélica e a estoica, porquanto a primeira leva em conta, como um fator importante para a manutenção da felicidade, evitar grandes males e infortúnios (o exemplo de Príamo, dado por Aristóteles, testemunha isso com clareza), enquanto para os estoicos a felicidade independe de quaisquer males ou infortúnios na medida em que todas essas coisas para eles 
não passam de adiaphora (indiferentes), categoria ética inventada pelos estoicos. Como resultado disso, temos duas ênfases distintas na concepção temporal: para Aristóteles, só se pode ser feliz se assim pudermos viver por um longo tempo e, na verdade, dado que desconhecemos o futuro e estamos submetidos à contingência, só podemos realmente ser ditos felizes e venturosos ao término de nossa vida, pois ignoramos que males e infortúnios ainda podem vir a se abater sobre nós. Para os estoicos, ao contrário, o que importa não é a mera quantificação do tempo, mas sim a sua qualidade. Assim, na perspectiva deles podemos ser felizes imediatamente se soubermos operar a cada momento a discriminação fundamental entre o que depende e o que não depende de nós. Desse modo, apesar de infortúnios e desgraças, que devem ser vividos como indiferentes, nada pode afetar a firmeza e constância do homem sábio, dado que a virtude depende única e exclusivamente dele esteja na circunstância que estiver.

É somente no segundo passo que as questões que realmente nos importam poderão ser discutidas, pois é nele que o termo bios pode ser traduzido como "modo de vida". Na verdade, depois de nossas considerações sobre a doxografia de Diógenes Laércio e sobre a influência estoica nela presente, é claro que devemos traduzir o vocábulo bios que nele ocorre como "modo de vida". Mas em Aristóteles, quando ele fala em bioi devemos traduzir o termo como "modos de vida" ou como "gêneros de vida"? Mais importante: há alguma relevância nessa escolha?

Acreditamos que, no espírito da filosofia do próprio Aristóteles, devemos estar atentos às ambiguidades terminológicas e às consequentes confusões que elas podem nos causar. Evidentemente, nos passos da obra aristotélica que discutem os bioi podemos traduzi-los por "modos de vida", mas é mister entender que para Aristóteles o significado desse termo não é o mesmo que aquele que o termo provavelmente tinha para os estoicos. Por conseguinte, talvez fosse mais apropriado no caso do Estagirita traduzi-lo por "gêneros de vida" como o faz M. Narcy em sua versão francesa (M. Gigante, ao contrário, prefere traduzir por "modos de vida"). Moraux indica alguns passos da obra de Aristóteles onde a divisão de diferentes espécies de vida seria encontrada, a saber: $E N 1.1095 b 19$, Pol. 7.1324a28 e $E E$ 1.1215a30. Vejamos o que diz Aristóteles em cada uma dessas passagens. No passo da Ética a Nicômaco, Aristóteles fala de três gêneros de vida, o do hedonista, o do político e o do teorético; na passagem da Política, ele associa a vida prática e a vida política que se contrapõem, por sua vez, à vida teorética ou filosófica, como ele também a denomina e, por fim, na Ética a Eudemo ele se refere igualmente aos três gêneros de vida: o do hedonista, o do político e o do filósofo. Fica clara, portanto, a associação entre a vida teorética e a vida filosófica por oposição aos outros dois gêneros de vida, o do hedonista e o do político. Destes tipos de vida, apenas 
a vida teorética ou filosófica parece possuir uma independência, fundamental para a sua escolha como o modelo mais adequado para uma vida feliz, visto que tanto o hedonista quanto o político na visão de Aristóteles serão sempre dependentes quer dos prazeres obtidos quer das honras e prestígios recebidos para serem felizes.

Ademais, é interessante lembrar que P. Moraux assinala também o fato que Diógenes Laércio resume, quase nos mesmos termos que ele usa para falar de Aristóteles, a posição dos estoicos relativa aos três modos de vida (7.130: Bíwv

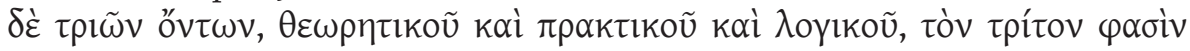

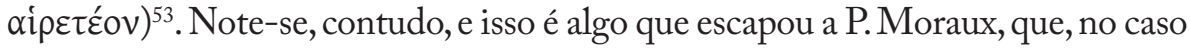
dos estoicos, o modo de vida que, segundo eles, deve ser escolhido é o racional ou lógico e não o teorético, o que deixa subentender que Diógenes Laércio é consciente de uma distinção conceitual entre um modo de vida teorético, tal como pensado por Aristóteles, e outro lógico ou racional, tal como concebido pelos estóicos. O modo de vida que não está citado no resumo concernente aos estoicos e que está presente no resumo sobre Aristóteles é o hedonista, os outros dois, o teorético e o prático, estão presentes tanto no resumo ético concernente a Aristóteles quanto no resumo relativo às doutrinas éticas dos estoicos. Isso parece significar que a vida teorética e a vida prática para os estoicos são opostas, tal como em Aristóteles, opõem-se a vida política e a vida teorética ou filosófica. Se isso for mesmo assim, fica claro então que a ideia de P. Hadot de subscrever a filosofia aristotélica no seu paradigma geral de conceber a filosofia antiga como modo de vida, não parece corresponder ao pensamento de Diógenes Laércio, pois este não iguala o modo de vida lógico ou racional ao modo de vida teorético. Assim, a vida teorética parece antes significar uma atividade apenas mental sem exigir ou pressupor uma transformação de todo o indivíduo. Richard Goulet em uma nota à sua tradução dessa passagem chama a atenção para o fato que logikou ("lógico" ou "racional") aqui não faz muito sentido, pois ele se relaciona tanto à vida prática quanto à teorética e sugere então que ele se refira a um modo de vida misto, chegando até mesmo a pensar em uma possível correção do manuscrito para miktou ${ }^{54}$, correção que nos parece um tanto quanto exagerada. A frase seguinte de Diógenes Laércio parece, todavia, confirmar essa hipótese de uma vida mista ao afirmar que "o animal racional foi gerado pela natureza

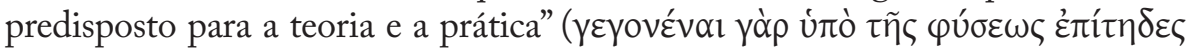

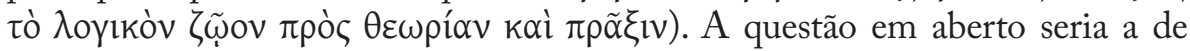
pensar se teríamos aqui uma vida mista, como pensa R. Goulet, ou antes, como nos propõe P. Hadot, uma alusão à distinção entre o discurso filosófico (seja ele prático ou teorético) e a vida filosófica.

\footnotetext{
${ }^{53}$ Cf. Moraux 194929.

${ }^{54}$ Cf. Goulet-Cazé 1999868 n. 1.
} 
Essa diferenciação entre o teorético, de um lado, e o racional ou lógico, de outro, parece indicar, portanto, uma diferença que Diógenes Laércio reconhece haver - apesar da influência estoica em seu resumo sobre a doutrina de Aristóteles - entre o significado de bios theoretikos para Aristóteles e o de bios logikos para os estoicos. Nesse ponto, apesar de P. Hadot, como vimos, servirse de alguns passos da obra de Diógenes Laércio para defender a sua leitura da filosofia antiga como um modo de vida, o antigo doxógrafo, entretanto, parece mais atento e cauteloso do que o intérprete contemporâneo quanto às diferenças existentes entre a escola peripatética e a escola estoica. Não nos parece, portanto, legítimo afirmar, como o faz, P. Hadot, que Aristóteles, ao usar o termo bios theoretikos esteja concebendo a filosofia como uma prática capaz de modificar toda a vida de um indivíduo por meio de exercícios de atenção, mas antes, apenas reconhecendo uma atividade intelectual que não se confunde com a atividade prática, embora em certa medida possa contribuir para esta. Como mostra E. Berti, a relação entre teoria e prática em Aristóteles é complexa, pois não se trata de uma relação de mera oposição, como nós estamos acostumados a pensar hoje em dia, mas sim de uma relação de continuidade, dado que a teoria aplicada, a phronesis, leva à boa conduta (eupraxia), assim como esta, por sua vez, conduz à vida teorética (bios theoretikos) como seu ápice.

Resta ainda o problema de ter de pensar um duplo sentido para o termo praktikos em Aristóteles, dado que a vida teorética é um gênero de vida, que, como bem nos lembra o passo da Política (cf.7.1325b16-21) citado por P.Hadot, mas infelizmente ignorado por E. Berti no artigo mencionado, é considerado igualmente uma vida de ação, mais ainda, a vida teorética é entendida como constituindo o sentido principal de ação. Ora, se a vida teorética é ação em seu sentido último, então fica difícil compreender a alternativa proposta por Aristóteles entre a vida do político e a do filósofo.

O passo da Política abre, contudo, uma possibilidade de distinção entre ações exteriores e interiores, de modo que, baseado nela, poderíamos entender que o arquiteto age e o faz em sentido mais próprio do que os pedreiros que constroem a casa, porque a sua construção é, por assim dizer, interior e independente de qualquer limitação exterior. Em termos aristotélicos: o pensamento é uma ação completa e perfeita (teleia) enquanto a construção é uma ação incompleta e imperfeita (ateles).

Vê-se, por conseguinte, que, embora Diógenes Laércio tenha sofrido uma forte influência estoica na sua apresentação da doutrina de Aristóteles, como mostraram cuidadosamente P. Moraux e R. Bodeüs, ele, não obstante, reconhece haver importantes diferenças entre as escolas peripatética e estoica, tal como essa que acabamos de mostrar relativa aos gêneros ou modos de vida propostos por ambas as escolas e passíveis de serem escolhidos pelos leitores de suas Vidas e doutrinas. É verdade que isso não é explicitamente 
discutido, mas apenas apresentado de modo sutil na enumeração dos modos de vida propostos e escolhidos por cada escola. Todavia, como vimos, o modo doxográfico de apresentação não se baseia em uma discussão conceitual dos argumentos opostos, mas sim na mera apresentação de possibilidades paralelas de escolha de diferentes modos de vida. Não nos esqueçamos que, excetuando-se o prólogo, os demais livros das Vidas e doutrinas de Diógenes Laércio foram estruturados precisamente para expor as distintas doutrinas das escolas filosóficas como alternativas de modelos de vida para os seus leitores. Logo, ainda que sutis essas diferenças eram essenciais para a apresentação da diversidade das escolas e não deveriam passar despercebidas para seus atentos leitores ávidos por escolherem o modo de vida filosófico mais compatível consigo mesmos.

Para concluir, não podemos afirmar, a partir dos passos que acabamos de analisar, que o célebre e paradoxalmente quase anônimo doxógrafo da Antiguidade, tenha incorrido em uma interpretação tão generalizante da filosofia antiga como um todo, tal como o fez em nossos dias P. Hadot. Acreditamos que esse cuidado na apresentação das doutrinas dos estoicos e dos peripatéticos relativo aos modos ou gêneros de vida mostra o quão arguto podia ser um autor antigo mesmo quando ele se predispunha a escrever aquilo que os filósofos, desde H. Diels, denominam , não sem certo menosprezo, um relato doxográfico. Resta-nos, portanto, a tarefa de refletir mais profundamente sobre o tipo de doxografia que Diógenes Laércio escreveu, mas isso já seria assunto para outro texto. 


\section{BibLIOGRAFIA}

E. Berti (2008), Nuovi studi aristotelici III: Filosofia pratica. Brescia, Morcelliana.

R. Bodéüs (1995), "L'aristotélisme stoïcien”, CEA 29 7-32.

D. Desroches (2011), "La philosophie comme mode de vie chez Pierre Hadot" in Encyclopédie de l'Agora. Grandes questions, Dossier thématique. 1-28. [disponível em <http://ddesroches.ep.profweb.qc.ca/Pdf/Pierre_ Hadot_Agora >; acedido a 10/06/13]

T. Dorandi (2007), "Diogène Laërce, 'lecteur' d'Aristote", Elenchos 28.2 435-446.

M. Foucault (2001), L'herméneutique du sujet. Cours au Collège de France 1981-1982. Paris, Gallimard/Le Seuil.

M. Frede (1992), "Doxographie, historiographie philosophique et historiographie historique de la philosophie”, Revue de Métaphysique et Morale 3 311-325.

M. Gigante (1986), "Biografia e dossografia in Diogene Laerzio", Elenchos 7 9-102.

( $\left.{ }^{3} 1987\right)$, Diogene Laerzio. Vite dei Filosofi. Intr., trad. e notas. Bari, Laterza.

M. Giusta (1964), I dossografi di etica, I. Torino, Giappichelli.

(1967), I dossografi di ética, II. Torino, Giappichelli.

M.-O. Goulet-Cazé, ed. (1999), Diogène Laërce. Vies et doctrines des philosophes illustres. Paris, Librairie Générale Française.

I. Hadot (1969), Seneca und die griechisch-römische Tradition der Seelenleitung. Berlin, De Gruyter.

P. Hadot (21987), "La philosophie comme manière de vivre" in P. Hadot, Exercices Spirituels et Philosophie Antique. Paris, Études Augustiniennes 217-227.

___ (1995), Quiest-ce que la philosophie antique? Paris, Gallimard.

A. Laks (2007), "Histoire critique et doxographie. Pour une histoire de l'historiographie de la philosophie" in A. Laks, Histoire, Doxographie, Vérité. Études sur Aristote, Théophraste et la Philosophie Présocratique. Louvain-la-Neuves, Éditions Peeters 13-26.

P. Moraux (1949), "L'exposé de la philosophie d'Aristote chez Diogène Laërce (V, 28-34)", RPhL 47 5-43.

(1986), "Diogène Laërce et le peripatos", Elenchos 7 247-294. 
C. Natali (1991), Bios Theoretikos. La vita di Aristotele e l'organizzazione della sua scuola. Bologna, Il Mulino.

P. Rabbow (1954), Seelenführung: Methodik der Exerzitien in der Antike. Munich, Kösel.

G. Reale (2005), Diogene Laerzio. Vite e dottrine dei più celebri fllosofi. Trad., intr. e notas. Milano, Bompiani.

M. G. Sollenberger (1992), "The Lives of the Peripatetics: An Analysis of the Contents and Structure of Diogenes Laertius' Vitae Philosophorum Book 5 " in W. Haase, ed. ANRW, II 36.6. Berlin/Nova Iorque, Walter de Gruyter 3793-3879.

S. Weil (1953), La source grecque. Paris, Gallimard. 